\title{
PERAWATAN BAYI BARU LAHIR (BBL) PADA IBU USIA PERKAWINAN KURANG DARI 18 TAHUN \\ (Di Wilayah Puskesmas Tiron Kabupaten Kediri)
}

Dian Rahmawati ${ }^{1}$ Delialika Ady Meiferina ${ }^{2}$

Akademi Kebidanan Dharma Husada Kediri Jawa Timur

\begin{abstract}
ABSTRAK
Bayi baru lahir (BBL) sangat rentan terhadap infeksi yang disebabkan oleh paparan virus dan kuman selama proses persalinan maupun beberapa saat setelah lahir. Perawatan BBL yang tidak tepat dapat menimbulkan masalah kesehatan pada bayi sampai kematian. Kesalahan tersebut dikarenakan kurangnya pengetahuan dan kesiapan ibu dalam perawatan BBL. Usia perkawinan ibu yang terlalu muda (kurang dari 18 tahun) memungkinkan kurangnya pengetahuan dan kesiapan ibu dalam perawatan BBL. Di Jawa Timur (2015), remaja yang menikah di usia dini sebanyak 53 per 1000 pernikahan dan angka rata-rata nasional 48 per 1000 pernikahan. Hasil wawancara terhadap 3 ibu BBL dengan usia kurang dari 18 tahun diketahui bahwa 2 orang $(66,67 \%)$ belum mengetahui cara merawat bayinya yang benar. Perawatan BBL yang dimaksud antara lain perawatan tali pusat, memandikan bayi, memberi minum, membersihkan telinga, membersihkan alat kelamin, mengganti popok bayi, dan menggunting kuku. Untuk itu penelitian ini bertujuan untuk mengetahui bagaimana perawatan BBL pada ibu usia perkawinan kurang dari 18 tahun di wilayah Puskesmas Tiron kabupaten Kediri.

Desain penelitian ini adalah deskriptif dengan pendekatan cross sectional. Populasi dalam penelitian ini adalah seluruh ibu dengan usia perkawinan $\leq 18$ tahun yang mempunyai BBL di wilayah puskesmas Tiron kabupaten Kediri. Dengan tehnik total sampling didapatkan sampel sebanyak 30 respoden ibu dengan usia perkawinan $\leq$ 18 tahun yang mempunyai BBL di wilayah puskesmas Tiron kabupaten Kediri. Pengumpulan data dengan kuesioner, wawancara dan observasi, kemudian dilakukan editing, coding,scoring, dan tabulating, selanjutnya data dianalisis dengan persentase.

Penelitian menunjukkan bahwa sebanyak 5 responden $(17 \%)$ melakukan perawatan BBL dengan kriteria baik, 19 responden (63\%) melakukan perawatan BBL dengan kriteria cukup, dan 6 responden (20\%) melakukan perawatan BBL dengan kriteria kurang.di Wilayah Puskesmas Tiron Kecamatan Banyakan Kabupaten Kediri.

Perawatan BBL pada ibu usia perkawinan $\leq 18$ Tahun di wilayah Puskesmas Tiron kabupaten Kediri secara keseluruhan menunjukkan sebagian besar cara perawatannya cukup sebanyak 19 responden (63\%).
\end{abstract}

Kata kunci :

Perawatan Bayi Baru Lahir (BBL), Ibu Usia Perkawinan kurang $\leq 18$ Tahun

Korespondensi: RT.004 RW.002 Ds. Bangkok Kec. Gurah Kab. Kediri Jawa Timur HP: 085645076003 ,email: lintangkayana31@gmail.com 


\section{PENDAHULUAN}

Bayi baru lahir (BBL) sangat rentan terhadap infeksi yang disebabkan oleh paparan virus dan kuman selama proses persalinan maupun beberapa saat setelah lahir. BBL membutuhkan perawatan dan perhatian karena bayi menjalani perubahan dari dunia dalam rahim ke dunia luar. Perawatan BBL yang tidak tepat dapat menimbulkan masalah kesehatan pada bayi sampai kematian.

Kesalahan dalam perawatan bayi yang dialami masyarakat dimungkinkan karena kurangnya pengetahuan dalam perawatan bayi, pendidikan dan sosial ekonomi yang masih rendah. Kesalahan dalam perawatan bayi terutama di daerah desa dan pelosok banyak dijumpai ibu yang baru melahirkan yang merawat bayinya dengan menggunakan cara tradisional. Selain itu juga dipengaruhi oleh kurangnya pengetahuan dan kesiapan ibu dalam perawatan BBL

Perkawinan di bawah umur semakin marak terjadi. Remaja desa kebanyakan malu kalau menikah pada umur 20 tahun ke atas terutama orang tuanya. Ada anggapan bahwa perempuan yang berumur 20 tahun ke atas dan belum menikah tidak laku atau disebut "perawan tua". Pemikiran tersebut jelas sangat berbeda dengan keadaan sekarang. Saat ini pernikahan muda dapat terjadi karena kehamilan di luar pernikahan. Seseorang yang sudah melangsungkan pernikahan pada umumnya berlanjut dengan kehamilan, persalinan dan perawatan bayi. Remaja yang terpaksa menjadi orang tua tentunya akan kesulitan merawat bayi mereka sendiri.

Usia perkawinan ibu yang terlalu

muda (kurang dari 18 tahun) memungkinkan kurangnya pengetahuan dan kesiapan ibu dalam perawatan BBL. Di Jawa Timur (2015), remaja yang menikah di usia dini sebanyak 53 per 1000 pernikahan dan angka rata-rata nasional 48 per 1000 pernikahan. Hasil wawancara terhadap $3 \mathrm{ibu}$ BBL dengan usia kurang dari 18 tahun diketahui bahwa 2 orang $(66,67 \%)$ belum mengetahui cara merawat bayinya yang benar. Perawatan BBL yang dimaksud antara lain perawatan tali pusat, memandikan bayi, memberi minum, membersihkan telinga, membersihkan alat kelamin, mengganti popok bayi, dan menggunting kuku.

Tujuan penelitian ini adalah untuk mengetahui bagaimana perawatan BBL pada ibu usia perkawinan kurang dari 18 tahun di wilayah Puskesmas Tiron kabupaten Kediri.

\section{METODE}

Desain penelitian ini adalah deskriptif dengan pendekatan cross sectional. Penelitian dilakukan di wilayah Puskesmas Tiron Kabupaten Kediri pada bulan Mei 2016. Populasi dalam penelitian ini adalah seluruh ibu dengan usia perkawinan $\leq 18$ tahun yang mempunyai BBL di wilayah puskesmas Tiron kabupaten Kediri. Dengan tehnik total sampling didapatkan sampel sebanyak 30 respoden ibu dengan usia perkawinan $\leq$ 18 tahun yang mempunyai BBL di wilayah puskesmas Tiron kabupaten Kediri. Variabel penelitian ini adalah variabel tunggal yaitu perawatan bayi baru lahir pada ibu usia perkawinan $\leq$ 18 tahun. Alat ukur yang digunakan adalah kuesioner, wawancara, dan observasi. Pengolahan data editing, coding, scoring, dan tabulating, selanjutnya data dianalisis dengan persentase. 


\section{DISKUSI}

\section{A. Hasil Kuesioner}

Tabel 1. Hasil analisis perawatan bayi baru lahir pada ibu usia perkawinan $\leq 18$ tahun di wilayah puskesmas tiron kabupaten Kediri

\begin{tabular}{|c|c|c|c|c|c|c|c|c|c|}
\hline \multirow{2}{*}{ No } & \multirow{2}{*}{ Variabel \& Sub Variabel } & \multicolumn{2}{|c|}{ Baik } & \multicolumn{2}{|c|}{ Cukup } & \multicolumn{2}{|c|}{ Kurang } & \multirow{2}{*}{ Total } & \multirow{2}{*}{$\begin{array}{l}\text { Persentase } \\
(\%)\end{array}$} \\
\hline & & $\mathbf{f}$ & $\%$ & f & $\%$ & f & $\%$ & & \\
\hline \multicolumn{10}{|c|}{ Variabel } \\
\hline Pera & vatan $B B L$ & 5 & 17 & 19 & 63 & 6 & 20 & 30 & 100 \\
\hline \multicolumn{10}{|c|}{ Sub Variabel : } \\
\hline 1 & Perawatan tali pusat & 8 & 27 & 12 & 40 & 10 & 33 & 30 & 100 \\
\hline 2 & Memandikan bayi & 5 & 17 & 15 & 50 & 10 & 33 & 30 & 100 \\
\hline 3 & Memberi minum & 6 & 20 & 11 & 37 & 13 & 43 & 30 & 100 \\
\hline 4 & Membersihkan telinga & 4 & 13 & 11 & 37 & 15 & 50 & 30 & 100 \\
\hline 5 & $\begin{array}{l}\text { Membersihkan alat } \\
\text { kelamin }\end{array}$ & 2 & 7 & 13 & 43 & 15 & 50 & 30 & 100 \\
\hline 6 & Mengganti popok bayi & 7 & 23 & 12 & 40 & 11 & 37 & 30 & 100 \\
\hline 7 & Menggunting kuku & 0 & 0 & 17 & 57 & 13 & 43 & 30 & 100 \\
\hline
\end{tabular}

Tabel 1 menunjukkan bahwa Perawatan bayi baru lahir (bbl) pada ibu usia perkawinan $\leq 18$ Tahun di wilayah puskesmas Tiron kabupaten Kediri secara keseluruhan menunjukkan sebagian besar cara perawatannya cukup sebanyak 19 responden $(63 \%)$. Dan untuk setiap sub variabel sebagai berikut :

1. Perawatan tali pusat bayi pada ibu usia perkawinan kurang dari 18 tahun mempunyai skor cukup yaitu sebanyak 14 responden (47\%).

2. Cara memandikan bayi pada ibu usia perkawinan kurang dari 18 tahun mempunyai skor cukup yaitu sebanyak 15 responden (50\%).

3. Cara memberi minum bayi pada ibu usi perkawinan kurang dari 18 tahun mempunyai skor kurang yaitu sebanyak 14 responden (47\%).

4. Cara membersihkan telinga bayi pada ibu usia perkawinan kurang dari 18 tahun mempunyai skor kurang yaitu sebanyak 15 responden (50\%).

5. Cara memberihkan alat kelamin bayi pada ibu usia perkawinan kurang dari 18 tahun mempunyai skor kurang yaitu sebanyak 15 responden (50\%).
6. Cara mengganti popok bayi pada ibu usia perkawinan kuran dari 18 tahun mempunyai skor cukup yaitu sebanyak 12 responden (40\%).

7. Cara menggunting kuku bayi pada ibu usia perkawinan kurang dari 18 tahun mempunyai skor cukup yaitu sebanyak 17 responden (57\%).

B. Hasil wawancara

1. Hasil wawancara pada 10 responden tentang perawatan tali pusat sebagi berikut :

Responden 1, 4, 9 : mengatakan "menurut saya perawatan tali pusat dengan memberi betadin pada kassa kemudian tali pusatnya dibungkus dengan kassa tersebut"

Responden 2, 3, 6, 8, 10 : mengatakan " menurut saya perawatan tali pusat dengan cara hanya dibungkus dengan kassa saja, dijaga jangan sampai basah"

Responden 5 : mengatakan "menurut saya merawatnya hanya dibiarkan tali pusat itu kering, kalau basah segera dikeringkan dengan kain bersih"

Responden 7 : mengatakan "menurut saya dengan dikasih suruh agar cepat kering" 
2. Hasil wawancara pada 10 responden tentang memandikan bayi sebagai berikut :

Responden 1 \& 5 : mengatakan “ memandikan bayi dengan cara diberi sabun keseluruh tubuh bayi, lalu dimasukkan dibak mandi yang berisi air hangat, kemudian membersihkannya di mulai dari muka"

Responden 2, 7, 9 : mengatakan “ memandikan bayi dengan cara bayi dimasukkan ke dalam bak mandi yang berisi air hangat, bayi dibersihkan dengan sabun dan dibilas didalam bak mandi tersebut"

Responden 3 : mengatakan "Memandikan bayi dengan cara bayi diletakan di atas meja, mengambil sedikit air di basuhkan keseluruh tubuh bayi. Lalu bayi disabun seluruh tubuh, dimulai dari muka di bilas dengan waslap yang dikasih air"

Responden 4, 6, 8, 10 : mengatakan "Memandikan bayi dengan cara meletakan bayi diatas meja dengan disabun seluruh tubuh, bayi di masukan bak mandi untuk dibilas"

3. Hasil wawancara pada 10 responden tentang memberi minum bayi sebagai berikut :

Responden 1, 4, 5, 10 : mengatakan "menurut saya dengan memberikan susu lewat dot bisa juga lewat gelas lalu disendok

Responden 2, 6, 9 : mengatakan "menurut saya cara memberi minum baru dengan dikasih ASI dengan posisi ibunya duduk, kemudian bayi dipangku.Setelah bayi selesai minum bayi disendawakan di pundak"

Responden 3, 7, 8 : mengatakan "menurut saya dengan cara menyusui posisi tidur miring. Kemudian badan bayi juga ikut miring menghadap ke ibu"
4. Hasil wawancara pada 10 responden tentang membersihkan telinga bayi sebagai berikut :

Responden 1 \& 3 : mengatakan "Dengan cara menggunakan cutembath dimasukan kedalam telinga dengan cara hati-hati”

Responden 2, 4, 10 : mengatakan "Saya biarkan saja,tidak saya bersihkan karena saya tidak berani"

Responden 5, 6, 8, 9 : mengatakan "Dengan cara menggunakan cuttembath yangdiberi baby oil lalu di masukan ke dalam telinga"

Responden 7 : mengatakan "Dengan cara menggunakan tangan yang diberi baby oil"

5. Hasil wawancara pada 10 responden tentang membersihkan alat kelamin bayi:

Responden 1, 2, 7 : mengatakan "menurut saya dengan cara membersihkan alat kelamin dengan tissu basah, lalu di bersihkan dengan sabun juga"

Responden 3, 9, 10 : mengatakan "menurut saya caranya membasahi kain bersih yang dibasahi dengan air dingin saja"

Responden 4, 5, 8 : mengatakan "menurut saya dengan menggunakan air bersih dari bagian yang bersih ke bagian yang kotor. Lalu dikasih sabun dan dikeringkan dengan kain kering yang bersih"

Responden 6 : mengatakan "menurut saya dengan cara dibersihkan dengan kain yang dibasahi dengan air hangat lalu dikeringkan. Setelah dikeringkan dikasih bedak sedikit"

6. Hasil wawancara pada 10 responden tentang mengganti popok bayi sebagai berikut :

Responden 1，3 10 : mengatakan "menurut saya dengan cara langsung 
mengganti popok ketika terlihat basah"

Responden 2 \& 6 : mengatakan "Bayi saya memakai pampes, menggantinya pampers sesering mungkin, kalau kelihatan sudah penuh"

Responden 4 \& 8 : mengatakan "Bayi saya memakai pampes, menggantinya disaat anak saya nangis dan kelihatan tidak nyaman"

Responden 5 : mengatakan "bayi saya memakai pampes, menggantinya kalau bayi saya selesai mandi”

Responden 7 \& 9 : mengatakan "Mengganti popok disaat bayi saya bak atau bab"

7. Hasil wawancara pada 10 responden tentang menggunting kuku bayi :

Responden 1,2,3,5,6,7 : mengatakan "Memotong kuku saat bayi tidur, dan merapikan kuku agar tidak terkena bagian tubuh yang lain"

Responden 4 \& 8 : mengatakan "Saya tidak berani memotong kuku bayi saya.takut kalau nanti melukai jari jari bayi saya"

Responden 9 : mengatakan "Saya memotong kuku bayi saya setelah bayi saya mandi,karena kukunya menjadi lunak"

\section{Hasil observasi}

Selain kuesioner dan wawancara, peneliti juga melakukan observasi. Dari 30 responden, observasi yang didapat yaitu :

1. Perawatan tali pusat

6 responden (17\%) melakukan perawatan tali pusat dengan baik. Sementara 14 responden (47\%) dengan baik. Sementara 9 responden $(30 \%)$ membersihkan alat kelamin cukup karena beberapa langkah tidak dilakukan. Sedangkan 14 melakukan perawatan tali pusat cukup karena beberapa langkah tidak dilakukan. Sedangkan 10 responden (33\%) tidak/kurang dalam merawat tali pusat karena banyak langkah yang tidak dilakukan.

\section{Memandikan bayi}

6 responden $(20 \%)$ memandikan bayi dengan baik. Sementara 14 responden (47\%) memandikan bayi dengan cukup karena ada beberapa langkah yang tidak dilakukan. Sedangkan 10 responden (33\%) tidak/kurang dalam memandikan bayi karena banyak langkah yang tidak dilakukan.

3. Memberi minum bayi

6 responden $(20 \%)$ memberikan minum dengan baik. Sementara 11 responden (37\%) memberi minum dengan cukup karena beberapa langkah tidak dilakukan. Sedangkan 13 responden (43\%) tidak/kurang dalam memberi minum bayi karena ada banyak langkah yang tidak dilakukan.

4. Membersihkan telinga

6 responden $(20 \%)$ membersihkan telinga dengan baik. Sementara 10 responden (33\%) membersihkan telinga dengan cukup karena beberapa langkah tidak dilakukan. Sedangkan 14 responden (47\%) tidak/kurang dalam membersihkan telinga karena ada banyak langkah yang tidak dilakukan.

5. Membersihkan alat kelamin 7 responden $(23 \%)$ membersihkan alat kelamin

responden (47\%) tidak/kurang dalam membershkan alat kelamin karena banyak langkah yang tidak dilakukan.

6. Mengganti popok bayi 
7 responden (23\%) dalam mengganti popok bayi baik. Sementara 15 responden $(50 \%)$ mengganti popok bayi cukup karena beberapa langkah tidak dilakukan. Sedangkan 8 responden $(27 \%)$ mengganti popok bayi tidak/kurang karena banyak langkah yang tidak dilakukan.

\section{Menggunting kuku bayi}

5 responden (17\%) dalam menggunting kuku bayi baik. Sementara 15 responden (50\%) dalam menggunting kuku bayi cukup karena beberapa langkah tidak dilakukan. Sedangkan 10 responden (33\%) dalam responden $(47 \%)$ dan untuk yang skor kurang sebanyak 10 responden (33\%).

Sebelum melakukan perawatan tali pusat, ibu harus mencuci tangan terlebih dahulu dan jika tali pusat terkena kotoran, segera cuci dengan air bersih dan sabun, lalu keringkan dengan kain bersih hingga benar-benar kering (Handy, 2011: 20-21). Dalam penelitian ini sebagian besar ibu dalam merawat tali pusat bayinya tidak mencuci tangan terlebih dahulu dan apabila tali pusat kotor setelah dibersihkan tidak dikeringkan dahulu dengan kain bersih.

\section{B. Memandikan bayi}

Berdasarkan hasil penelitian, dari 30 responden diketahui bahwa sebanyak 15 responden $(50 \%)$ memandikan bayinya dengan skor cukup. Dari hasil wawancara dengan 10 responden, responden tersebut sudah cukup mengerti cara memandikanC.
bayi yang benar. Dan berdasarkan hasil observasi dari 30 responden, untuk skor baik sebanyak 6 responden $(20 \%)$, skor cukup sebanyak 14 responden (47\%) dan skor kurang sebanyak 10 responden $(33 \%)$.

Memandikan bayi adalah salah satu cara perawatan untuk memelihara menggunting kuku tidak/kurang karena banyak langkah yang tidak dilakukan.

\section{A. Perawatan tali pusat}

Berdasarkan hasil penelitian, dari 30 responden diketahui bahwa sebanyak 12 responden $(40 \%)$ merawat tali pusat bayinya dengan skor cukup. Dari hasil wawancara dengan 10 responden, responden tersebut sudah cukup mengerti cara perawatan tali pusat yang baik. Dan berdasarkan hasil observasi dari 30 responden, untuk skor baik sebanyak 6 responden (20\%), untuk yang skor cukup sebanyak 14

kesehatan dan kenyamanan (Wahyuni, 2011: 81). Bayi tidak perlu dimandikan dan dikeramas setiap hari. Dua sampai tiga kali seminggu sudah cukup selama area genital dan wajah tetap dibersihkan setiap hari. Keramas yang sering justru menyebabkan kulit kepala bayi kering (Kelly, 2010: 46).

Gunakan waslap lembut dan sabun yang ringan, mulai dengan membersihkan wajah bayi, telinga kemudian lehernya. Pada saat memandikan, perhatikan lipatan leher dan sela-sela jari tangan dan jari kaki, demikian juga jika memandikan dengan waslap saja kemudian bilas sampai bersih. Pada penelitian ini sebagian ibu dalam memandikan bayinya tidak dimulai dari wajahnya tetapi langsung ke badan bayi. Setelah badan kemudian baru ke wajah.

\section{Memberi minum}

Berdasarkan hasil penelitian, dari 30 responden diketahui bahwa sebanyak 13 responden (43\%) mempunyai skor kurang dalam cara memberi minum bayinya. Dari hasil wawancara dengan 10 responden, responden tersebut masih kurang mengerti cara memberi minum pada bayi yang benar. Dan berdasarkan hasil observasi 
dari 30 responden, untuk skor kurang dalam memberi minum pada bayinya sebanyak 13 responden (43\%).

Berikan ASI sesering mungkin sesuaiE. keinginan bayi atau sesuai keinginan ibu (jika payudara penuh) atau sesuai kebutuhan bayi setiap 2-3 jam (paling sedikit 4 jam), berikan secara bergantian. (Rukiyah \& Yulianti, 2012: 66). Pada penelitian ini sebagian besar ibu memberi minum/ASI bayinya pada saat bayinya menangis saja dan kelihatan lapar. Kebanyakan pada saat bayinya tidur ibu membiarkan tidak memberi minum sesuai jadwalnya yaitu setiap 2 jam sekali.

\section{Membersihkan telinga}

Berdasarkan hasil penelitian, dari 30 responden diketahui bahwa sebanyak 15 responden $(50 \%)$ mempunyai skor kurang dalam cara membersihkan telinga bayinya. Dari hasil wawancara dengan 10 responden, responden tersebut masih kurang mengerti cara membersihkan telinga bayi yang benar. Dan berdasarkan hasil observasi dari 30 responden, untuk skor kurang dalam cara membersihkan telinga pada bayinya sebanyak 13 responden $(43 \%)$.

Menjaga kebersihan sangatlah penting bagi kesehatan bayi, apalagi pada bagian telinga. Selain bermanfaat untuk mencegah menumpuknya kotoran,F membersihkan telinga juga bisa menghilangkan sel-sel mati yang telah menumpuk pada lipatan telinga (Pondokibu, 2015). Telinga yang tidak dijaga kebersihannya, akan menimbulkan infeksi pada telinga karena menumpuknya kotoran pada telinga. Kotoran pada telinga yang tidak rajin dibersihkan akan mengganggu kesehatan telinga bayi. Dalam penelitian ini sebagian besar ibu dalam membersihkan telinga bayinya tidak masih takut, takut kalau nanti masuknya kapas batang terlalu dalam dan ada juga yang takut sehingga tidak dibersihkan karena belum pernah melakukannya sebelumnya.

\section{Membersihkan alat kelamin}

Berdasarkan hasil penelitian, dari 30 responden diketahui bahwa sebanyak 15 responden $(50 \%)$ mempunyai skor kurang dalam cara membersihkan alat kelamin bayinya. Dari hasil wawancara dengan 10 responden, responden tersebut masih kurang mengerti cara membersihkan alat kelamin bayinya yang benar. Dan berdasarkan hasil observasi dari 30 responden, untuk skor kurang dalam cara membersihkan telinga pada bayinya sebanyak 14 responden (47\%).

Setiap kali bayi buang air besar, maka segera bersihkan daerah bokong bayi, agar tidak lecet dan mengganggu kenyamanan bayi, karena jika daerah bokong lembab dan kotor mudah mengalami lecet sehingga nantinya bayi akan rewel. Untuk membersihkan daerah bokong, sebaiknya memakai air bersih hangat dan sabun, kemudian segera keringkan dengan handuk secara lembut (Rukiyah \& Yulianti, 2012: 70-71). Dalam penelitian ini, sebagian besar ibu masih belum mengerti dan masih belum bisa membersihkan alat kelamin bayinya dengan benar.

\section{Mengganti popok bayi}

Berdasarkan hasil penelitian, dari 30 responden diketahui bahwa sebanyak 12 responden $(40 \%)$ mempunyai skor cukup dalam cara mengganti popok bayinya. Dari hasil wawancara dengan 10 responden, responden tersebut cukup mengerti cara mengganti popok bayinya dengan benar. Dan berdasarkan hasil observasi dari 30 responden, untuk skor cukup dalam cara mengganti popok bayi sebanyak 15 responden $(50 \%)$.

Waktu terbaik untuk mengganti popok adalah setelah bayi BAB dan setelah bayi ngompol. Mengganti popok biasanya 1012 kali sehari. Akan tetapi, yang akan 
membuat kewalahan untuk mengurusnya. Apabila bayi tidak mengalami masalah ruam popok serius, tidak perlu selalu mengganti popok pada malam hari. Jika bayi dapat tidur nyenyak, dapat dipastikan bayi merasa nyaman (Kelly, 2010: 43).

Dalam mengganti popok bayi, harus selalu diganti apabila bayi BAB dan BAK, karena kalau tidak segera diganti akan membuat bayi rewel dan sering menangis. Tidak segera mengganti popok pada saat bayi BAB atau BAK juga akan menyebabkan iritasi pada kulit bayi karena lembab. Dalam penelitian ini, sebagian ibu dalam mengganti popok bayinya dilakukan apabila bayi BAB dan apabila tidak $\mathrm{BAB}$ hanya diganti waktu sesudah mandi pagi dan sesudah mandi sore.

\section{G. Menggunting kuku}

Berdasarkan hasil penelitian, dari 30 responden diketahui bahwa sebanyak 17 responden $(57 \%)$ mempunyai skor cukup dalam cara meggunting kuku bayinya. Dari hasil wawancara dengan 10 responden, responden tersebut cukup melukai bagian tubuh bayinya yaitu dengan mengenakan sarung tangan dan sarung kaki pada bayi

\section{KESIMPULAN}

Perawatan Bayi Baru Lahir (BBL) pada Ibu Usia Perkawinan kurang dari 18 Tahun di Wilayah Puskesmas Tiron Kecamatan Banyakan Kabupaten Kediri

\section{DAFTAR PUSTAKA}

Ariani, Ayu Putri. (2014). Aplikasi Metode Penelitian Kebidanan dan Kesehatan Reproduksi. Yogyakarta: Nuha Medika

Departemen Pendidikan Nasional. (2008). Kamus Besar Bahasa mengerti cara menggunting kuku bayinya dengan benar. Dan berdasarkan hasil observasi dari 30 responden, untuk skor kurang dalam cara mengganti popok bayi sebanyak 15 responden (50\%).

Menjaga agar kuku bayi baru lahir tetap pendek adalah hal yang penting untuk perlindungan bayi itu sendiri. Selama bayi bermain dengan jari-jarinya, dengan mudah dapat mencakar wajahnya sendiri jika kuku jarinya tidak pendek dan dipotong dengan rata. Seiring dengan makin besarnya bayi, kuku jari yang pendek adalah untuk perlindungan ibu (Kelly, 2010: 55-56).

Kuku bayi harus dijaga dengan baik karena kuku yang panjang akan menjadi tempat bakteri. Kuku bayi juga harus selalu digunting apabila sudah terlihat panjang karena kalau kuku bayi panjang akan membahayakan bayi itu sendiri, bisa mencakar kulit wajah bayi. Pada penelitian ini sebagian ibu yang takut mengguting kuku bayinya, takut kalau terkena kulit jari bayinya. Sehingga hal yang dilakukan ibu agar kuku bayi tidak

secara keseluruhan menunjukkan sebagian besar cara perawatannya cukup sebanyak 19 responden $(63 \%)$.

Indonesia Pusat Bahasa Edisi IV. Jakarta: PT. Gramedia Pustaka Utama

Departemen Kesehatan Republik Indonesia. (2009). Pelayanan Kesehatan Neonatal Esensial : Pedoman Teknis Pelayanan Kesehatan Dasar. Jakarta

Handayani, Nina. (2011). Buku Pintar Merawat Bayi. Jakarta: Dian Rakyat 
Handy, Fransisca. (2011). Panduan Cerdas Perawatan Bayi. Jakarta: Pustaka Bunda

Hidayat, A.Aziz Alimul. (2009). Metode Penelitian Keperawatan dan Teknik Analisis Data. Jakarta: Salemba Medika

Hidayat, A.Aziz Alimul. (2010). Metode Penelitian Kebidanan dan Teknik Analisis Data. Jakarta: Salemba Medika

Kelly, Paula. (2010). Buku Saku Asuhan

Neonatus dan Bayi. Jakarta: EGC

Nursalam. (2014). Metode Penelitian Ilmu Keperawatan. Jakarta: Salemba Medika

Rukiyah, Yeyeh. (2012). Asuhan Neonatus Bayi dan Anak Balita. Jakarta: TIM

Saifuddin, Abdul Bari. (2006). Buku Acuan Nasional Pelayanan Kesehatan Maternal Dan Neonatal. Jakarta : YPB-SP

Setiadi. (2007). Konsep dan Penulisan Riset Keperawatan. Yogyakarta: Graha Ilmu

Setiyaningrum, Erna. (2015). Pelayanan Keluarga Berencana dan Kesehatan Reproduksi Edisi Revisi. Jakarta: TIM

Sugiyono. (2012). Metode Penelitian. Bandung: Alfabeta
Sujarweni, V. Wiratna. (2014). Metode Penelitian. Yogyakarta: PUSTAKABARUPRESS

Wahyuni, Sari. (2011). Asuhan Neonatus, Bayi dan Balita: Penuntun Belajar Praktik Klinik. Jakarta: EGC

Wawan dan Dewi. (2010). Teori dan Pengukuran Pengetahuan, Sikap dan Perilaku Manusia. Yogyakarta: Nuha Medika

Undang-Undang Perkawinan dan Administrasi Kependidikan Kependudukan, Kewarganegaraan. (2015). Tim Permata Press

Adi. (2014). BKKN Rekomendasikan Usia Minimal Perkawinan 20 tahun. Diakses pada 25 April 2016 jam 15.15

Anissa, Riski. (2015). Intensitas Orang Tua Dalam Pengambilan Keputusan Untuk Melakukan Pernikahan Anak Di Bawah 20 Tahun. Diakses pada 25 April 2016 jam 15.15

Gustaman. (2015). Angka Pernikahan Dini Di Jawa Timur Lebih Tinggi Dari Rata-Rata. [Diakses pada 25 April 2016 jam 16.00

Majalah Pondokibu. (2015). Cara Membersihkan Telinga Bayi Bayi Baru Lahir Dengan Aman. Diakses pada 25 april 2016 jam 15.00 